\title{
Recent patents in gene expression
}

\begin{tabular}{|c|c|c|c|c|c|}
\hline Patent \# & Subject & Assignee & Author & $\begin{array}{l}\text { Priority } \\
\text { application } \\
\text { date }\end{array}$ & $\begin{array}{l}\text { Publication } \\
\text { date }\end{array}$ \\
\hline WO 200127275 & $\begin{array}{l}\text { Novel G-protein coupled receptor polynucleotides } \\
\text { used to produce recombinant receptor polypeptides; } \\
\text { for use in screening assays for modulators of gene } \\
\text { expression or protein activity. }\end{array}$ & $\begin{array}{l}\text { Lexicon Genetics } \\
\text { (The Woodlands, } \\
\text { TX) }\end{array}$ & $\begin{array}{l}\text { Donoho G, } \\
\text { Hilbun E, } \\
\text { Nehls M, } \\
\text { Sands AT, } \\
\text { Turner CA, } \\
\text { Wattler F, } \\
\text { Zambrowicz B }\end{array}$ & 10/13/1999 & 4/19/2001 \\
\hline WO 200127329 & $\begin{array}{l}\text { Detection of gene expression and analysis of both } \\
\text { known and unknown genes by obtaining a DNA } \\
\text { comprising an anchorable moiety, cleaving the DNA } \\
\text { with two restriction endonucleases, ligating two linker } \\
\text { molecules to the cleaved DNA, and amplifying } \\
\text { the ligated DNA. }\end{array}$ & $\begin{array}{l}\text { Univ. Texas } \\
\text { System } \\
\text { (Austin, TX) }\end{array}$ & $\begin{array}{l}\text { Aldaz CM, } \\
\text { Gaddis SS, } \\
\text { Macleod MC }\end{array}$ & 10/8/1999 & $4 / 19 / 2001$ \\
\hline US 6218142 & $\begin{array}{l}\text { New nucleic acid molecules encoding polypeptides } \\
\text { with RNA-directed RNA polymerase enzymatic } \\
\text { activity; useful in modulating gene expression in } \\
\text { plants, humans, and animals, as well as in plant } \\
\text { cell/tissue cultures or plant breeding. }\end{array}$ & $\begin{array}{l}\text { Riedel L, } \\
\text { Wassenegger M, }\end{array}$ & $\begin{array}{l}\text { Riedel L, } \\
\text { Sanger HL, } \\
\text { Schiebel W, } \\
\text { Wassenegger M }\end{array}$ & $3 / 5 / 1997$ & $4 / 17 / 2001$ \\
\hline WO 200124821 & $\begin{array}{l}\text { A screening process for an agent that alters bone } \\
\text { mineralization that comprises contacting a cell } \\
\text { containing } N E L L-1 \text { gene with a test agent and detect- } \\
\text { ing a change in } N E L L-1 \text { gene expression level; useful } \\
\text { for facilitating bone calcification or repair. }\end{array}$ & $\begin{array}{l}\text { Regents of the } \\
\text { Univ. of } \\
\text { California } \\
\text { (Oakland, CA) }\end{array}$ & Ting $\mathrm{K}$ & 10/5/1999 & $4 / 12 / 2001$ \\
\hline WO 200123614 & $\begin{array}{l}\text { Computer-related determination of the relative level } \\
\text { of a biological molecule, for example, nucleic acid, in } \\
\text { experiments for analyzing gene expression data; } \\
\text { comprises performing principal component analysis. }\end{array}$ & $\begin{array}{l}\text { Affymetrix } \\
\text { (Santa Clara, } \\
\text { CA) }\end{array}$ & Ho M & $5 / 31 / 2000$ & $4 / 5 / 2001$ \\
\hline EP 1089211 & $\begin{array}{l}\text { The display of gene expression patterns for the } \\
\text { determination of the different roles of the genes; } \\
\text { comprises the comparison and analysis of the } \\
\text { expression of multiple genes at different time points. }\end{array}$ & $\begin{array}{l}\text { Hitachi Software } \\
\text { Eng. Co. Ltd. } \\
\text { (Yokohama, } \\
\text { Japan) }\end{array}$ & $\begin{array}{l}\text { Nakashige R, } \\
\text { Nozaki Y, } \\
\text { Tamura T, } \\
\text { Watanabe T }\end{array}$ & 9/30/1999 & $4 / 4 / 2001$ \\
\hline US 6211164 & $\begin{array}{l}\text { New antisense oligonucleotides used to inhibit gene } \\
\text { expression of the human Chk1 gene; particularly } \\
\text { useful as therapeutic agents for enhancing the sensit- } \\
\text { ivity of tumor cells to radiation or chemotherapy. }\end{array}$ & $\begin{array}{l}\text { Abbott } \\
\text { Laboratories } \\
\text { (Abbott Park, IL) }\end{array}$ & $\begin{array}{l}\text { Giranda VL, } \\
\text { LuoY, } \\
\text { Rockow- } \\
\text { Magnone SK }\end{array}$ & $3 / 10 / 2000$ & $4 / 3 / 2001$ \\
\hline JP 2001083164 & $\begin{array}{l}\text { A rigid macroarray used as a support for fixing test } \\
\text { samples containing biopolymers such as DNA; } \\
\text { useful for gene expression analysis and basic } \\
\text { sequence determination. }\end{array}$ & $\begin{array}{l}\text { Fuji Photo } \\
\text { Film Co. } \\
\text { Ltd. (Tokyo) }\end{array}$ & - & 9/17/1999 & $3 / 30 / 2001$ \\
\hline WO 200120006 & $\begin{array}{l}\text { A polynucleotide with a target gene linked to a novel } \\
\text { chemically inducible promoter; useful for controlling } \\
\text { eukaryotic target gene expression and in gene therapy. }\end{array}$ & $\begin{array}{l}\text { Zeneca } \\
\text { (London) }\end{array}$ & $\begin{array}{l}\text { Caddick MX, } \\
\text { Croft K, } \\
\text { Greenland AJ, } \\
\text { Jepson I, } \\
\text { Martinez A, } \\
\text { Tomsett AB, } \\
\text { Tregova A }\end{array}$ & 9/15/1999 & $3 / 22 / 2001$ \\
\hline WO 200120041 & $\begin{array}{l}\text { Quantitating gene expression by using genomic DNA as an } \\
\text { internal amplification competitor and without nucleic acid } \\
\text { amplification or primer binding, as expressed by the ratio } \\
\text { of messenger RNA to genomic DNA; particularly useful } \\
\text { for quantitating estrogen receptor expression. }\end{array}$ & $\begin{array}{l}\text { Xtrana } \\
\text { (Broomfield, } \\
\text { CO) }\end{array}$ & $\begin{array}{l}\text { Gerdes JC, } \\
\text { Marmaro JM }\end{array}$ & 9/17/1999 & $3 / 22 / 2001$ \\
\hline NL 1012782 & $\begin{array}{l}\text { A new variant of the green fluorescent protein gene } \\
\text { that has better solubility and/or a shifted excitation } \\
\text { spectrum; useful for genetic or expression labeling. }\end{array}$ & $\begin{array}{l}\text { Keygene NV } \\
\text { (Wageningen, } \\
\text { the Netherlands) }\end{array}$ & $\begin{array}{l}\text { de Both MTJ, } \\
\text { Frijters ACJ }\end{array}$ & 8/5/1999 & 2/6/2001 \\
\hline
\end{tabular}

Source: Derwent Information, Alexandria, VA. The status of each application is slightly different from country to country. For further details, contact Derwent Information, 1725 Duke Street, Suite 250, Alexandria, VA 22314. Tel: 1 (800) DERWENT (info@derwent.com). 